\section{A ÉTICA DA PSICANÁlISE E A REPETIÇÃO DO ENCONTRO FALTOSO DO REAL}

\section{Psychoanalysis's Ethics and the Repetitive Missing Encounter of the Real}

\section{La Ética del Psicoanálisis y la Repetición del Encuentro Fallido de lo Real}

\section{L'éthique de la Psychanalyse et la Répétition de la Rencontre Manquée du Réel}

\begin{abstract}
Resumo
Este artigo aborda, segundo a psicanálise, o problema da repetição e suas implicações éticas diante da demanda de felicidade dos que chegam a um analista. Parte-se da premissa psicanalítica de que o mal-estar é intrínseco ao ser humano, na medida em que, em vez do programa anônimo dos instintos, o homem é um ser de linguagem, atravessado pelo mal-entendido da fala, por desejos singulares e dissimétricos, e satisfações parciais. Neste contexto, a repetição é abordada desde suas origens freudianas no âmbito do além do princípio do prazer, passando pelas contribuições de Lacan, principalmente pelo seu uso das noções da Física aristotélica: tykhe e automaton. Ademais, a demanda de felicidade é confrontada com o destino de repetir, como por acaso, o encontro faltoso do real da pulsão, que tem uma bela ilustração literária no poema Acaso de Álvaro de Campos. Dessa forma, considera-se que, não estando a serviço do encontro feliz do prazer nos bens, como em terapêuticas que oferecem receituários normativos de adaptação, a ética psicanalítica concerne à ex-sistência do sujeito fixado a uma posição sintomática de gozo, cujo tratamento se concentra nas vias do bem-dizer o sintoma, o que resulta na conquista de uma posição subjetiva que mobiliza e inclui o desejo inconsciente sem o custo de tanto sofrimento.
\end{abstract}

Palavras-chave: psicanálise; ética; repetição; felicidade; desejo.

\section{Abstract}

This article discusses, in the face of happiness demands of those arriving at an analyst, the repetition problem and its ethical implications according to psychoanalysis. It starts from the psychoanalytical premiss of the intrinsic human discontent, in so far as instead of the anonymous programme of instincts, man is a linguistic being crossed by the misunderstandings of speech, singular asymmetric desires, and partial satisfactions. In this context, repetition is taken from its Freudian origins beyond the pleasure principle, through to Lacan's main contributions, especially in his use of two physical Aristotelic notions: tykhe and automaton. Moreover, happiness demand is confronted with one's destiny towards repetition of the faulty encounter, as if by chance, with the real within the pulsion, which has a beautiful literarily illustration by Acaso, an Álvaro de Campos' poem. Not engaging with the happiness encounter of pleasure within goods, such as other therapies offering normative recipes for adaptation, psychoanalysis's ethics is concerned with the ex-sistence of the subject fixated within a symptomatic position of jouissance, whose treatment concentrate on the ways of say-well the symptom, which results in the conquest of a subjective position that mobilises and includes the unconscious desire without such high-suffering cost.

Keywords: psychoanalysis; ethics; repetition; happiness; desire.

\section{Resumen}

Este artículo analiza, según el psicoanálisis, el problema de la repetición y sus implicaciones
Artigo Original
1) Psicanalista. Doutorando em Teoria Psicanalítica na Universidade Federal do Rio de janeiro, com estágio doutoral financiado pela CAPES na Université Paris 8 Vincennes-Saint-Denis. Bolsista de Doutorado do CNPq.

2) Psicanalista. AME da Escola de Psicanálise dos Fóruns do Campo Lacaniano. Membro do Campo Psicanalítico, Professora adjunta do Instituto de Psicologia da UFBA. Doutora em Teoria Psicanalítica pela UFRJ.
Recebido em: 15/06/2012 Revisado em: 05/09/2013 Aceito em: 21/08/2014 
éticas delante de la demanda de felicidad de los que llegan hasta un analista. Se parte de la premisa psicoanalítica que el malestar és intrínseco al ser humano, a medida que, en lugar del programa anónimo de los instintos, el hombre és un ser de lenguaje, entrecortado por el malentendido del discurso, por los deseos singulares y disimétricos, y las satisfacciones parciales. En este contexto, la repetición és analizada desde sus orígenes freudianas en el ámbito del más allá del principio del placer, pasando por las contribuciones de Lacan, en especial por su uso de las nociones de la Física Aristotélica: thykhe y automaton. Además, la demanda de felicidad és confrontada con el destino de repetir, como una causalidad, el encuentro fallido de lo real de la pulsión, que tiene una bonita ilustración literaria en el poema Acaso de Álvaro de Campos. Así, se considera que, al no estar a servicio del encuentro feliz del placer en los bienes, como en terapéuticas que ofrecen recetas normativas de adaptación, la ética psiconalítica concierne la ex-sistencia del sujeto fijado a una posición sintomática de goce, cuyo tratamiento concentrase a través de bien-decir lo sintoma, lo que resulta en la conquista de una posición subjetiva que mueve $y$ incluye el deseo inconsciente sin el coste de tanto sufrimiento.

Palabras clave: psicoanálisis; ética; repetición; felicidad; deseo.

\section{Résumé}

Dans une perspective psychanalytique, cet article a comme sujet la question de la répétition et ses implications éthiques en réponse à la demande du bonheur posée à l'analyste. On part de la notion psychanalytique du malaise comme intrinsèque à l'être humain, dans la mesure où, à l'opposé de l'anonymat caractéristique des instincts, l'homme est un être parlant, dont la parole est traversée par un malentendu inévitable, par des désirs singuliers et dissymétriques, et par des satisfactions partielles. Dans ce contexte, on part du concept freudien de la répétition, au-delà du principe du plaisir, pour ensuite prendre en compte les contributions lacaniennes dans leurs rapports avec la notion de tykhe et automaton, qu'on trouve dans la Physique d'Aristote. D'ailleurs, la demande de bonheur est confronté à la repetition comme au hasard de la rencontre manquée du réel de la pulsion. Dans le poème Acaso de Álvaro de Campos, on trouve une belle illustration littéraire de ce cadre. Par conséquent, on considère que, n'étant pas au service de la rencontre heureuse du plaisir, comme c'est le cas des thérapeutiques qui offrent des recettes d'adaptation normatives, l'éthique psychanalytique s'occupe de l'ex-sistence du sujet et de son mode symptômatique de jouir, dont le traitement se concentre sur un bien-dire. Cela a pour effet la conquête d'une position subjective qui mobilise et intègre le désir inconscient sans autant de souffrance.

Mots-clés: psychanalyse; étique; répétition; bonheur; désir.

\section{Da Disciplina Aristotélica da Felicidade ao Princípio do Prazer Freudiano}

A postulação da felicidade sempre se articulou com uma ética dos bens, sendo identificada ao Sumo Bem especialmente na antiguidade greco-latina. Formalmente, enquanto disciplina filosófica dedicada à reflexão acerca dos juízos e normas adotados pelos sistemas morais, a ética começou com Aristóteles, responsável pela fundação da disciplina e por formular suas principais questões. Entre elas estão a relação entre as normas e os bens, a categorização das virtudes, os âmbitos individual e social da ética etc. Depois dele, na Grécia, muitas escolas filosóficas se ocuparam da ética. Todas possuíam, inclusive, dois traços comuns.

Primeiro, considerar a ética como ética dos bens, isto é, estabelecer uma hierarquia de bens concretos aos quais os homens aspiram e pelos quais se mede a moralidade de seus atos. Segundo, buscar a tranqüilidade do ânimo, que segundo alguns (os estóicos) se encontra na impassibilidade, segundo outros (os cínicos) no desprezo pelas convenções e segundo outros (os epicuristas) no prazer moderado ou, melhor, no equilíbrio racional entre as paixões e a sua satisfação. (Mora, 2001, tomo II, p.932)

$\mathrm{Na}$ Grécia, existia uma particular vinculação entre os bens e o bem-estar, com a suposição de que, na Natureza, está inscrita uma tendência que conduz à felicidade aqueles que distinguem os falsos bens dos verdadeiros. Neste debate, há o problema da admissão dos universais: entidades abstratas gerais que orientam as teorias éticas e os sistemas morais. O status ontológico dos universais define um modo especial de valorizar e conceber a justiça e o bem. E a despeito das divergências das escolas - platônica, aristotélica, estóica -, um mesmo postulado se conservou uníssono na Grécia Antiga: o de que o universal Bem Supremo existe. E "o signo de sua presença soberana nos bens é a sensação de sentir-se bem, vivendo n'Ele e por Ele" (Julien, 1996, p. 25, grifo nosso).

O Bem Supremo é uma noção cunhada por Aristóteles (1979), para indicar o absoluto e incondicional Bem, ou seja, aquilo que é desejado por si mesmo e não em vista de outro bem, evitando o processo ao infinito. Para Aristóteles, o Bem Supremo é a felicidade, pois ninguém a escolhe tendo em vista outra coisa que não seja ela mesma. Diferentemente ocorre à honra, ao prazer, à razão e a todas as virtudes, que, apesar de serem escolhidas por elas mesmas, também são tomadas no interesse de outra coisa - a felicidade.

Aristóteles, entretanto, advertira que ser a felicidade o Sumo Bem talvez pareça uma banalidade, faltando explicar mais claramente o que ela é. Para sabê-lo, seria indispensável indagar sobre a função do homem, pois, "para todas as coisas que têm uma função ou atividade, considerase que o bem e o bem feito (grifo nosso) residem na função" (Aristóteles, 1979, p. 55). Então, excluindo a vida de nutrição e percepção, que são comuns a outros seres vivos, ele concluiu que "a função do homem é uma atividade da alma que segue ou que implica um princípio racional" (p. 56), sendo a função de um bom homem a nobre realização 
das ações da alma. Neste sentido, o bem do cidadão grego é a ação racional conforme a virtude, predicado obtido pelo mesotes: a via da moderação ligada ao princípio de evitamento do vício, ou de todo excesso.

Todavia, é mister destacar que a reflexão dos gregos acerca da ação humana e de seu ethos não resultava em ordenações minuciosas a respeito de como agir (faça isso, abstenha-se daquilo), como ocorre nos códigos sob a égide da moral judaico-cristã. Para os gregos, interessava mais a relação de si mesmo com a ação, no sentido mais amplo de domínio, limitação e repartição da atividade. Assim, primava-se pela técnica da vida virtuosa, não pela codificação imediata dos atos (Foucault, 1984).

Os antigos gregos, porque consideravam a felicidade possível, tomavam-na como um dever. Para eles, "a felicidade é possível porque há uma ordem do mundo segundo a qual o bem e a felicidade conjugam-se num mesmo ponto que os finaliza soberanamente" (Julien, 1996, p.25). Assim, professavam o bom encontro: "Admite-se geralmente que toda arte e toda investigação, assim como toda ação e toda escolha, têm em mira um bem qualquer; e por isso foi dito, com muito acerto, que o bem é aquilo a que todas as coisas tendem" (Aristóteles, 1979, p.49).

Por outro lado, o homem antigo sempre esteve submetido ao Deus do destino, que lhe conferia de antemão uma dívida a ser paga em vida. Isso constituía a fatalidade, a Até grega. Por isso, o grego, com freqüência, maldizia o Deus do destino por ser cruel e lhe ter conferido uma sorte trágica. A famosa expressão "Ah! Antes não ter nascido" do Coro no Édipo em Colono de Sófocles (2001), também teve lugar na ética de Aristóteles (2002), que asseverou ser melhor não nascer do que ser vítima de enfermidades extremas, de dores excessivas e tempestades devastadoras. Neste contexto, da mesma forma que o Deus do destino participava no infortúnio, ele também estava presente na prosperidade, mesmo quando as coisas dependiam do homem e de sua conformidade com os princípios da ação virtuosa. Quer dizer, embora a felicidade não fosse concedida pelos deuses - mas, ao contrário, resultante da virtude -, ela também era contada entre as coisas divinas, pois o prêmio e a finalidade da virtude se afiguravam como o que de melhor existe no mundo: algo de divino e abençoado (Aristóteles, 1979, p. 59).

Neste sentido, é preciso destacar a diferença de cosmovisão radical entre a antiguidade grega e a modernidade. Na primeira, a Natureza obedecia a um curso cíclico, que determinava a razão da vida. O imutável e o constante eram álibis da verdade e norteavam a visão de mundo dos gregos. A dimensão circular do Tempo não separava claramente o sagrado do profano (Arendt, 2002). Por isso, o Deus do destino e o universo humano compunham o mesmo movimento esférico da Natureza. Assim, através das virtudes, a felicidade era o fim soberano intrínseco à Natureza.

De fato, o homem grego só era homem ao sujeitar-se à Natureza. Esta se conservava a mesma no macrocosmo e no microcosmo, que é psique. Por isso, segundo Aristóteles (1979), havia uma espécie de logos universal. Isso levou os gregos a sustentar que todos querem ser felizes e tendem para o encontro do Bem, considerando que há um ponto final em que todos são aguardados, onde repousa o objeto em que felicidade e bem coincidem.

Em tempos modernos, não sobreviveu a unidade cíclica da Natureza, em que macrocosmo e microcosmo são coextensivos, apesar de apenas o primeiro ser o lugar do sagrado. A famosa frase de Kant, inscrita em seu túmulo, indica essa cisão do pensamento moderno com a antiguidade: "Duas coisas lhe enchiam o coração de admiração e de veneração sempre renovada, ou seja, a lei moral em seu recôndito e o céu estrelado sobre o ser" (Kant, 1959, p.111). O respeito e a admiração de Kant ao céu estrelado e à lei moral em seu recôndito não são da mesma ordem de outrora, quando da antiguidade grega. As leis físicas celestes não têm mais nada a dizer a respeito da lei moral em seu recôndito íntimo do ser, pois há um corte entre elas.

Também se diluiu a idéia do Bem Supremo como um Ser. O desenvolvimento da ciência moderna mostra isso, numa relação estreita com a ética.

O Cosmo pré-galileano estabelecia uma hierarquia segundo a qual o ser era dado como um valor - sendo todo princípio de ordem simultaneamente físico e ético - a ser compreendido segundo a verdade e o bem. Com Galileu, Descartes e Newton, todos os estados do mundo tornaram-se equivalentes; portanto, não há porque buscar numa Física, na Natureza, qualquer referencial da ordem das causas finais ou de consideração do melhor para esclarecer e sustentar o nosso ato ético. A realidade física tornou-se totalmente desumana: nada mais de amizade das aparências, nada mais de sinal de conivência entre elas e nós! (Koyré, 1973, citado por Julien, 1996, p. 29)

Neste contexto, a ruptura entre o macrocosmo e o microcosmo foi sentida no desencantamento científico do mundo, no esteio da perspectiva linear da História e do surgimento do homem angustiado diante de sua finitude e do seu desamparo no mundo. Não é à toa que a Modernidade também abrangeu a elaboração de uma Filosofia da História que secularizou os princípios teológicos. Com Hegel, “que a verdade reside e se revela no próprio processo temporal é característico de toda consciência moderna, como quer que essa se expresse - em termos especificamente hegelianos 
ou não" (Arendt, 2002, p. 101). Da Antigüidade, portanto, eliminaram-se o imutável e o constante enquanto álibis da verdade.

Neste abismo que separa o mundo antigo do moderno, observamos certa constante: por um lado, Aristóteles (1979) acreditava que o homem visa a felicidade como Bem Supremo, traçando o ethos da ação que conduz a ela. Por outro lado, em sua interrogação acerca do mal-estar na Civilização, Freud asseverou que, enfim, os homens almejam a felicidade em última instância: "O que pedem eles da vida e o que desejam nela realizar? A resposta não pode provocar dúvidas. Esforçam-se para obter felicidade; querem ser felizes e assim permanecer" (Freud, 1930/1997, p.23).

Entretanto, as perspectivas destes dois autores acumulam uma distância de muitos séculos e diferenças substanciais de Cosmovisão e de princípios ético-filosóficos. O gênio moderno e científico de Freud não consolidou uma ética dos bens calcada no mito coletivo e na Cosmovisão circular entre o macrocosmo da Natureza e o microcosmo da psique, nem tampouco se amparou em categorias universais do Ser, pelas quais o bem e a ação moderada tenderiam para o Bem Supremo da felicidade. Ademais, a partir do século XIX, em cuja segunda metade nascera Sigmund Freud, temse, por exemplo, o registro da virada ética do utilitarismo, encarnado em seu autor mais célebre, Jeremy Bentham, que introduziu uma nova perspectiva para o bem e para a felicidade. Bentham considerou que o utilitarismo estaria a serviço de uma reforma dos costumes da sociedade e de sua estrutura política, que devia ser liberal e democrática.

A base da reforma utilitarista era a constatação de que o homem estaria sob o domínio de dois senhores - a dor e o prazer. O princípio de utilidade de Bentham, também conhecido como princípio da máxima felicidade, admite a submissão do homem a estes dois mestres e propõe uma norma de conduta a partir disso: consentir ou dissentir de uma ação de acordo com a tendência da conduta de aumentar ou reduzir a felicidade do envolvido na situação, seja um indivíduo, seja uma comunidade. Dessa forma, Bentham concebeu uma moral utilitarista cujas normas gravitam entre evitar a dor (o mal, o infortúnio) e promover o prazer (o bem, a felicidade) (Mora, 2001, tomo IV).

Nesta perspectiva, o bem e a felicidade não são entidades metafísicas nem universais. Ao contrário, estariam estritamente sujeitos ao cálculo dos prazeres e dores envolvidos no âmbito das trocas entre os homens. Assim, a felicidade repousaria nos prazeres encontrados no serviço dos bens.

Curiosamente, "é nesse contexto que a análise aparece - sem que possamos saber exatamente o que justifica que seja nesse contexto -, e que o analista se oferece para receber, é um fato, a demanda de felicidade" (Lacan, 1997, p. 351). Afinal, o utilitarismo prescreve a felicidade para todos, numa amplitude democrática. E isso quer dizer que todo cidadão comum adquiriu o direito de ser feliz - uma prerrogativa sem precedentes na História.

A partir das elucubrações de Lacan (1997) a respeito da ética da psicanálise, pode-se localizar uma afinidade do utilitarismo com a perspectiva do sujeito freudiano, mas que não dá conta da novidade que Freud introduziu no domínio ético. É sabido que Freud alinhou a felicidade com o programa do princípio do prazer, com horizontes de rebaixamento de tensões desprazerosas e vivência de sentimentos intensos de prazer. Contudo, deve-se ressaltar que Freud e Bentham não foram os primeiros, nem os únicos, a meditar acerca do bem em função do índice de prazer. Isso já era pensado desde a origem do pensamento ético, com os gregos.

Acontece que Bentham e Freud têm em comum o fato de abordarem a questão do bem de forma moderna e peculiar, quer dizer, no nível do significante, em vez de no âmbito do Ser. Veículo do prazer e do programa da felicidade, o bem está longe de ser pura e simplesmente o Bem natural no horizonte de uma tendência universal. Antes, a felicidade no bem está no nível simbólico da partilha e da rivalidade, ou seja, no seio do poder dialético de satisfazer e privar.

O homem moderno é este homem freudiano do mito individual do neurótico e da referência da felicidade identificada ao programa do princípio do prazer intrínseco ao aparato psíquico, que é representado pela ideia do maquinário simbólico encarnado no organismo vivo, definindo uma energética entrópica de subtração e perda, que tem dois limiares de satisfação feliz: uma meta positiva, que visa à experiência de sentimentos de prazer; e uma meta negativa com o objetivo de evitar o sofrimento. Acontece que, quando descreveu as três grandes fontes do sofrimento humano - o destino de decadência do corpo, a natureza com suas forças esmagadoras de destruição e o relacionamento com os outros homens -, Freud (1930/1997) assinalou que a felicidade, assentada no princípio do prazer, era impossível de ser alcançada, mormente devido ao modo de funcionamento do aparato psíquico em face das tensões do circuito pulsional e da parcialidade das satisfações humanas, marcadas por uma falta lancinante e irredutível, que aliena o sujeito numa deriva de repetição de gozo, além do princípio do prazer.

\section{A Incorporação do Simbólico e o Aparato Psíquico Freudiano}

A partir de Lacan, seguir o debate metapsicológico de Freud implica, inevitavelmente, em uma topologia do sujeito na linguagem. Pois bem, parte-se, aqui, deste 
pressuposto psicanalítico de que, diferentemente dos demais seres vivos, o homem é um ser de linguagem. Aliás, é notável a sua maior distinção: ser dotado e orientado pela sua capacidade de falar. E isso cobra um preço a ser pago, qual seja: sem roteiros subjetivos prévios, o homem está confinado no mundo do mal-entendido da linguagem, no qual a materialidade da palavra vocalizável no campo do dizer, sem sentido unívoco no ato da fala, comanda o seu destino.

Em lugar do consolidado programa do saber instintivo e inato, o homem nasce destinado à linguagem, na qual se escrevem a gramática das pulsões, o aparato psíquico, e se conforma um corpo. Entretanto, o humano não nasce com nada disso constituído. Ele precisa encontrar, na alteridade humana que o antecede, os elementos de sua entrada como sujeito no mundo simbólico. Neste sentido, é notável, por exemplo, que os incômodos que o recém-nascido manifesta, com berros enigmáticos e expressões dúbias, são berros enigmáticos e expressões dúbias porque precisam ser interpretados, ou seja, precisam ser tomados na ordem do pedido. Assim, em vez do programa anônimo dos instintos, a linguagem humana é constitutiva e veiculada por seres falantes, que portam desejos particulares e são por eles orientados no cuidado e interpretação do que afeta e satisfaz a criança (Lacan, 1998b).

O saber instintivo e programado nos animais se refere à uniformidade de um sistema de signos e de significados padronizados, comprometidos com os referentes da vivência animal. Aqui, entende-se vivência no sentido do ser vivo que não constitui um mundo através da linguagem, nem perfaz história transmissível pela palavra (Benjamin, 1996). Ao contrário, ele permanece no campo do saber instintivo, da referência imediata à coisa real e da comunicação estereotipada na interface com o semelhante (rival e parceiro), no âmbito dos rituais imaginários de comunicação dos perigos, dos cantos e danças de acasalamento e de ostentação agressiva.

Por outro lado, a despeito de também experimentarem os efeitos do registro imaginário (a sedução e a agressividade diante da imagem do semelhante, parceiro ou rival), os homens encontram o muro da linguagem que os separa da coisidade real dos objetos, dos semelhantes e de si mesmos. O desprendimento entre a fala do sujeito e o real da coisa concerne à ex-sistência ${ }^{1}$ da realidade humana, marcada pela

1 Expressão utilizada por Lacan em alusão à ideia de Heidegger (1991) de que o homem vive na clareira do ser. Para Lacan, a condição de ser de linguagem do sujeito, ou seja, o fato de ele ser um efeito da cadeia significante da fala, institui certa relação de exterioridade com o real (relação de ex-sistência). Neste contexto, o real é o limite de impossível do dizer sobre o ser vivo e sexuado na linguagem. Portanto, a ex-sistência é a existência subjetiva do ser falante, vivida com a presença estranha e familiar do real da coisa enquanto dimensão irredutível à predicação simbólica nas emergências do gozo no corpo. mortificação da coisa através da palavra. Por isso, o homem é uma espécie animal à parte, com esta esdrúxula condição de falta-a-ser, na qual a marca simbólica da falta é a forma negativa do ser na linguagem. Por isso, somente o homem tem a peculiaridade de derivar na cadeia significante da fala, sem garantias prévias da significação encontrada nos pontos de parada desta cadeia, e que o representam como sujeito no campo da linguagem (Lacan, 1998a).

Neste sentido, a partir da sua releitura do texto freudiano, Lacan (1998c) reconheceu, na psicanálise, a condição de campo do saber devotado à fala e à linguagem. No esteio desta consideração, Lacan (1998d) postulou que o inconsciente é estruturado como uma linguagem, demarcando também dois campos: o do sujeito e o do Outro. Este último, em especial, é "o lugar em que se situa a cadeia do significante que comanda tudo que vai poder presentificar-se do sujeito, é o campo desse vivo onde o sujeito tem que aparecer" (p. 194). Por isso, o rebento humano nasceria com uma carência primordial: a falta de encarnação dos significantes que the representam como sujeito no discurso do Outro.

Dessa forma, o advento do sujeito tem suas peculiaridades. A entrada no mundo humano e a abordagem da realidade se dão através da encarnação da linguagem como aparelho de gozo (Lacan, 1985). Mas o que isso significa? Primeiramente, considera-se a realidade da estrutura de linguagem. De que se trata? Respondendo negativamente à segunda pergunta proposta pelo entrevistador Robert Georgin - se a noção de estrutura não poderia reunir em um campo comum a psicanálise, a etnologia e a linguística - Lacan (2003a, p. 405) indicou o que é particular da psicanálise no trato da estrutura, definindo que é preciso seguir os efeitos da linguagem na medida em que o simbólico toma corpo, ou seja, é incorporado e, no mesmo lance, confere um corpo a alguém, no sentido comum de possuir um corpo. Em outros termos, é o corpo do simbólico, corpo incorpóreo, que, sendo incorporado, faz do organismo um corpo. Das palavras de Lacan, destacamos o seguinte:

A estrutura é apanhada a partir daí. Daí, isto é, do ponto em que o simbólico toma corpo. [...] Volto primeiro ao corpo do simbólico, que convém entender como nenhuma metáfora (grifo nosso). Prova disso é que nada senão ele isola o corpo, a ser tomado no sentido ingênuo, isto é, aquele sobre o qual o ser que nele se apóia não sabe que é a linguagem que lho confere, a tal ponto que ele não existiria, se não pudesse falar. $O$ primeiro corpo faz o segundo, por se incorporar nele (grifo nosso). Daí o incorpóreo que fica marcando o primeiro, desde o momento seguinte à sua incorporação. (Lacan, 2003, pp. 405-406) 
Destaca-se desta passagem a ideia de excluir o sentido metafórico da incorporação do corpo simbólico, que resulta num corpo incorpóreo por ser incorporado. Não sendo metafórico o sentido deste corpo incorporado e tornado incorpóreo, a sua literalidade material de encarnação, por outro lado, parece próxima do sentido matemático de corpo, quer dizer, do corpo enquanto conjunto de relações internas a uma estrutura, que satisfaz um universo de dados, e que, neste caso, engendra o corpo carnal como um aparelho linguageiro de gozo (Jadin \& Ritter, 2009, p. 256). Somente assim, a partir do significante incorporado, a estrutura produz na carne os efeitos de afeto, de sentido e de conformação imaginária dos corpos.

Pois bem, as vias por onde Freud apresentou o funcionamento do aparato psíquico são as mais diversas e fascinantes. Desde o longo e neurológico texto do Entwurf (Freud, 1895/1996a), passando pela Traumdeutung (Freud 1900/1996b), pelos artigos metapsicológicos de 1914-1915 e posteriores, entre os quais destacamos o curto e denso Die Verneinung (Freud, 1980/1925). Em toda a metapsicologia, observa-se o empenho de Freud em definir a constituição do aparato psíquico de linguagem como rede de captura, fixação, retenção e transformação das excitações no corpo, através de traços mnêmicos (Garcia-Roza, 1999a). Por isso, ele precisou supor um momento originário, mítico, no qual o bebê ainda não incorporou o simbólico, e cujas vias de satisfação são encontradas na relação com a alteridade humana frente à qual se constituem os sujeitos.

No pensamento freudiano, a realidade psíquica resulta do encontro com a alteridade que se apresenta ao bebê, e que foi denominada de próximo (Nebenmensch) ainda quando Freud (1895/1996a) se valia do aparato conceitual da neurologia, ou seja, quando o que fora depois pensado como representante psíquico era debatido em termos de rede neuronal. Na fundação da realidade, a relação com o próximo encerraria um composto de duas dimensões. A primeira é a sua condição de semelhante, pela qual é capaz de humanizar o bebê através dos predicados simbólicos das identificações, da especularidade imaginária como suposição de mútua compreensão etc. A segunda dimensão do próximo é a que está além da predicação do semelhante: é a Coisa (das Ding). Pode-se dizer que a Coisa é o próximo estritamente real, o Outro inominável, fora do significado, estranho e estrangeiro a cada um. É o imprevisível que não pode ser circunscrito nem domado pela palavra. Lacan (1997) o localizou no plano real da extimidade, procurando condensar, em seu neologismo, a estranheza e a familiaridade da presença íntima da Coisa real excluída da predicação simbólica.

Lacan (1997, p. 58) também situou, na condição de Coisa (Chose em francês, derivada do latim Causa) desta alteridade freudiana radical do próximo, a complexidade causal do sujeito nas fímbrias dos registros do real, do simbólico e do imaginário. Por isso, ele atentou para o rigor terminológico de Freud (1915/1996f), que não utilizara Ding, mas o termo alemão Sache na composição da expressão "representação de coisa" (lemos Sachvorstellung e não Dingvorstellung). Isso se justificaria pelo fato de que a coisa da representação de coisa (die Sache), que é grafada com minúscula para se diferenciar da Coisa (das Ding), está intimamente ligada à representação de palavra (Wortvorstellung), que "faz o homem colocar em questão suas palavras como referindo-se às coisas que, no entanto, elas criaram" (Lacan, 1997, p. 61). Quer dizer, a coisa (die Sache) é coisa simbolizada, atravessada pelo significante, produto da indústria ou da ação humana governada pela linguagem. Em Linguística e em Comunicação, ela corresponde ao referente da realidade objetiva, ou seja, à coisa do mundo que a palavra (die Wort) nomeia.

Por outro lado, a dupla dimensão do próximo (Nebenmensch) freudiano, enquanto alteridade humana radical, se desdobra também em Coisa (das Ding) real, situada em extimidade em relação à estrutura significante e à coisa predicada pelo simbólico e pelo imaginário do corpo (die Sache). Acontece que, para conceber o próximo nesta dupla dimensão, Freud (1895/1996a) partiu da constatação de que o infante permanece, por algum tempo, incapaz de realizar, por si só, a ação específica que garante sua sobrevivência. Ele depende de ajuda para experimentar a satisfação através dos seus mecanismos internos. Durante certo período inicial, as experiências de satisfação promovem três consequências fundamentais para o advento do psiquismo, ou do sistema $\Psi$ do Entwurf de Freud: primeiro, uma descarga permanente; segundo, uma catexização de neurônio(s) correspondente(s) à percepção do objeto; e, por fim, uma disseminação das "informações sobre a descarga do movimento reflexo liberado que se segue à ação específica" (Freud, 1895/1996a, p. 370), descarga esta limitada a um grupo de neurônios.

Estas catexias ou ligações neuronais foram denominadas por Freud de trilhamentos (Bahnungen) entre imagens mnêmicas, quer dizer, trilhamentos mentais que, em razão da lei básica de associação por simultaneidade, são catexizados quando o estado de urgência ou desejo é repetido por estimulação. Ou seja, os traços de memória seriam reativados quando uma nova moção de desejo surgisse. Esta moção produziria a alucinação do objeto, ou seja, um esforço da memória de reencontrar a satisfação primeira através da identidade de percepção do objeto. Entretanto, somente o teste de realidade da percepçãoconsciência, secundariamente, permitiria localizar algo que satisfaça, ao menos de modo aproximativo na realidade, os predicados do objeto alucinado.

Observa-se que, do encontro repetido com a Coisa real 
primeva, fixa-se um rastro mnêmico da satisfação obtida; e um elemento significante do sistema de traços de memória instaura a alucinação da satisfação no lugar vazio da Coisa real. Neste contexto, cabe ressaltar que, desde os seus textos pré-psicanalíticos, Freud atinou para um aspecto decisivo da estruturação do aparato psíquico. Nos sistemas de traços de memória, o destino não é o reencontro do objeto real. Dessa forma, da Coisa como Outro real, e supostamente absoluto, restaria o desígnio de objeto perdido e o rastro redutível a traços psíquicos, em cujos circuitos se desenrolaria o pensamento, que define, no espelho do semelhante, os bens cabíveis para a redução das tensões decorrentes das moções de desejo.

Ao mesmo tempo em que a memória inconsciente se funda nesta rede significante, resta do objeto real uma dimensão arredia à simbolização, que Freud (1895/1996a) denominou de neurônio $\alpha$, e que se refere ao predicado real da Coisa no objeto alucinado: nome do lugar vazio deixado pelo objeto real, em razão da fundação do aparato psíquico; nome do real no qual tropeça a homeostase psíquica da alucinação e de sua função defensiva nos termos do princípio do prazer. Das Ding é a realidade de gozo, de pathos que comove a pulsão a nunca deixar de esforçar-se em busca da satisfação completa, ou seja, na repetição da tendência para a experiência última de gozo. E

a diferença de quantidade entre o prazer da satisfação que é exigida e a que é realmente conseguida, é que fornece o fator impulsionador que não permite qualquer parada em nenhuma das posições alcançadas, mas, nas palavras do poeta, 'ungebandigt immer vorwarts dringt' ('pressiona sempre pra frente, indomado'). (Freud, 1920/1996c, pp. $52-53)$

É cediço que até o ano de 1920, a lógica freudiana do aparelho psíquico era regida pelo soberano princípio do prazer, que busca a homeostase, ou seja, que a elevação da tensão é vivida como desprazer e seu rebaixamento como prazer. Todavia, na teoria freudiana, o desprazer deixou de se configurar apenas como o correlato do prazer a ser reduzido em seu excesso, adquirindo também o caráter de uma dimensão heterogênea, que forçou Freud a levar em consideração um além do princípio do prazer.

Esta nova modalidade de desprazer tem a peculiar característica de se repetir na vida das pessoas como um compromisso inconsciente com o penar. Entre os neuróticos, Freud observou a notável compulsão a repetir um sofrimento e a alcançar os mesmos resultados negativos como por acaso, acompanhados do sentimento de ser perseguido por um destino maligno. Dois exemplos são o homem cujas amizades sempre findam por uma traição por parte dos amigos, e o amante cujos casos amorosos atravessam as mesmas fases e terminam da mesma forma. Diante disso, Freud concluiu taxativamente: "existe realmente na mente uma compulsão à repetição que sobrepuja o princípio do prazer" (Freud, 1920/1996c, p. 33).

No "Além do Princípio do Prazer", onde abordou a questão da repetição, Freud (1920/1996c) fez referências diretas às neuroses traumáticas, em que circunstâncias de falta de defesas contra uma grande ruptura produzem um trauma. Ao trauma freudiano, Lacan associou o real, que irromperia com a pulsão e não seria inteiramente assimilado pela trama significante. Assim, longe de uma teoria mecânica ou fisiológica do trauma, Freud postulou que é da pulsão proveniente do corpo que emerge a ruptura traumática, tão exterior ao aparelho psíquico quanto os excessos de estimulação advindos do mundo externo.

Portanto, é com a premência da pulsão que o sujeito tem de se haver. E a ruptura causada pelo trauma só pode ser pensados a partir da borda que se pode produzir em torno de. O trauma, então, apresenta-se como o demasiado do pulsional, frente ao qual as facilitações mnêmicas se articulam insuficientemente. Por isso, "o trauma é concebido como devendo ser tamponado pela homeostase subjetivante que orienta todo o funcionamento definido pelo princípio do prazer" (Lacan, 1998d, p. 57).

A esta homeostase subjetivante dos trilhamentos inconscientes resiste um núcleo real que corresponde a das Ding. De fato, Freud sempre esteve às voltas com um aparelho psíquico que é a escrita de uma trama simbólica incapaz de domar inteiramente a Coisa enquanto o Outro real; e que instaura a deriva da satisfação parcial com objetos cujas peculiaridades são determinadas pelos trilhamentos inconscientes. Isso define o encontro faltoso da satisfação, além de circunscrever o trauma como invariante da estrutura, e não um acidente de desafortunados, como sugerem os acasos repetidos na vida.

Neste sentido, é importante indicar que, quando Lacan (1998b) designou o real como instância topológica referida ao traumático e ao gozo, ele se valeu da tykhe, categoria da Física aristotélica relacionada ao acaso. Neste acaso, tratase do lacaniano "acaso necessário" da estrutura a partir de uma perda real, que funda o voltar sempre ao mesmo lugar desta falta lancinante, repetindo o encontro brusco e faltoso do real inassimilável. Por isso,

(...) o que se repete não poderia estar de outro modo, em relação ao que repete, senão em perda. Em perda do que quiserem, em perda de velocidade, de força - há algo que é perda. Freud insiste desde a origem, desde a articulação que estou resumindo aqui, nessa perda - na própria repetição há desperdício de gozo. (Lacan, 1992, pp. 44) 
Assim, neste contexto em que as marcas diferenciais da linguagem cunham o psíquico, o sujeito é o efeito de significação de uma cadeia significante singular, marcada por uma falta intrínseca. De outra parte, das Ding é o objeto real que encarna a perda do inassimilável de gozo da entrada na linguagem. Afinal, a linguagem trama a satisfação e a sua perda simultaneamente, ou seja, fornece as trilhas do gozo, mas faz delas a vereda da repetição das satisfações parciais.

\section{A Ética da Psicanálise no Acaso do Encontro Faltoso do Real}

Advertidamente, Lacan nos indicou, quando as coordenadas do seu estudo da ética se definiam, que "o termo felicidade, em quase todas as línguas, apresenta-se em termos de encontro - tykhe" (Lacan, 1997, p. 23). Em francês, felicidade (bonheur) se decompõe etimologicamente em bon (que se traduz bom) e heur (fortuna, sorte), que é homófono de heurt (encontro brusco). Assim, tem-se o bom encontro, a boa hora, designando a felicidade. Somente em inglês, felicidade não é tykhe, encontro. Ainda assim, é bem próximo: "Happiness é, no entanto, happen, é também um encontro, embora não se sinta a necessidade aqui de se acrescentar a partícula precedente marcando o caráter, propriamente falando, feliz da coisa" (p. 23).

Para abordar a repetição do encontro faltoso do real, Lacan (1998d) apelou para duas categorias da Física de Aristóteles - tykhe e automaton - distinguidas no sentido de estabelecer a noção de causa acidental (Symbebekos). Por serem causas acidentais, incluem-se na categoria de causa eficiente ou motora, ou seja, no princípio de movimento ou mudança de uma coisa. Tykhe e automaton distinguemse das demais causas eficientes por apresentarem o caráter da excepcionalidade, concorrendo na produção de acontecimentos que escapariam da inteligibilidade da razão humana (Garcia-Roza, 1999b).

Designar uma causa oculta para a ação humana não implicava, entre os gregos, que a tykhe devesse ser assimilada ao caráter absurdo de certos fenômenos. Ao contrário, "a tyche grega designava em geral uma divindade desconhecida - porém nomeada -, responsável pela sorte ou infortúnio dos homens" (Garcia-Roza, 1996b, p. 40). Antigos poetas gregos, como Arquíloco de Paros, consideravam a tykhe a força divina sobre o destino humano, de que muitos desejavam se livrar para alcançar a independência e a liberdade. Além dos poetas, também filósofos como Platão se referiram à tykhe divina, responsável pela sorte do indivíduo e da Polis. Assim, a tykhe, antes de Aristóteles, comportava a mística idéia de destino (Garcia-Roza, 1996b).

Enquanto a tykhe estava ligada a uma necessidade (fortuna) desconhecida do homem, mas deliberada pelos deuses, a automaton era tomada no sentido mais estritamente ligado à noção de acaso, daquilo para o que não houve quem deliberasse. Não à toa a expressão automaton comporta 0 sentido de algo que se move por si mesmo. Este acaso da automaton era, contudo, secundário, pois estava sempre ligado a uma regra natural, a uma ordem que the antecedia, mas de que era exceção.

Aristóteles retomou a tykhe de seus antecessores, destituindo-a do caráter místico e lhe dando lugar na causalidade física. Ele conservou, entretanto, o caráter de destino da tykhe, sendo o acaso introduzido como aquilo que na tykhe designa o "encontro de duas séries causais, cada uma perfeitamente determinada, ficando o caráter de excepcionalidade referido ao encontro de uma com a outra." (Garcia-Roza, 1996b, p. 41). O exemplo de alguém que vai à praça fazer negócios e se encontra por acaso com um devedor, que lhe paga o que devia, sinaliza o acaso como acidente articulador de duas séries causais independentes, não como produto da desordem.

Lacan (1998d) se apropriou destas duas categorias aristotélicas para articular o conceito de repetição na psicanálise. Partindo da formulação de que o inconsciente é estruturado como uma linguagem, ele concebeu a automaton como o retorno dos signos, a insistência da cadeia significante inconsciente em determinar os atos, posto que organizada de uma determinada maneira. Assim, ninguém agiria sem uma razão, sem um sentido, pois um ato teria sempre algo de estrutura, ou melhor, de estrutura de linguagem. A rede inconsciente de traços tenderia a repetir o que subjaz de insistência do desejo. Assim, a repetição de fracassos e de tropeços seria, antes de tudo, o compromisso do sujeito com um saber inconsciente de que está alienado o eu da consciência, que estranha a suposta fatalidade casual do seu destino.

Por sua vez, a tykhe se refere ao que se repete como falta, ou como o inassimilável do trauma pelas representações insistentes da automaton, quer dizer, do retorno dos signos sobredeterminados pela estrutura de linguagem. A tykhe é o encontro do real. Lacan utilizou uma fórmula spinoziana para marcar o limite do real: cogitatio adaequata semper vitat eamdem rem - um pensamento adequado evita sempre a mesma coisa. Por isso, "o real é aqui o que retorna sempre ao mesmo lugar - a esse lugar onde o sujeito, na medida em que ele cogita, onde a res cogitans, não o encontra" (Lacan, 1998d, p.52).

Neste sentido, há um poema chamado "Acaso", de Álvaro de Campos, heterônimo de Fernando Pessoa (1998, p. 376), com o qual se pode ilustrar bem o que está em jogo da repetição em psicanálise. 


\section{Acaso}

No acaso da rua o acaso da rapariga loira.

Mas não, não é aquela.

A outra era noutra rua, noutra cidade, e eu era outro.

Perco-me subitamente da visão imediata,

5 Estou outra vez na outra cidade, na outra rua,

E a outra rapariga passa.

Que grande vantagem o recordar intransigentemente! Agora tenho pena de nunca mais ter visto a outra rapariga, E tenho pena de afinal nem sequer ter olhado para esta.

10 Que grande vantagem trazer a alma virada do avesso!

Ao menos escrevem-se versos.

Escrevem-se versos, passa-se por doido, e depois por gênio, se calhar

Se calhar, ou até sem calhar,

Maravilhas das celebridades!

15 Ia eu dizendo que ao menos escrevem-se versos...

Mas isso era a respeito de uma rapariga,

De uma rapariga loira,

Mas qual delas?

Havia uma que vi há muito tempo numa outra cidade

20 Numa outra espécie de rua;

E houve esta que vi há muito tempo numa outra cidade

Numa outra espécie de rua;

Por que todas as recordações são a mesma recordação,

Tudo que foi é a mesma morte,

25 Ontem, hoje, quem sabe se até amanhã?

Um transeunte olha para mim com uma estranheza ocasional.

Estaria eu a fazer versos em gestos e caretas?

Pode ser... A rapariga loira?

É a mesma afinal...

30 Tudo é o mesmo afinal...

Só eu, de qualquer modo, não sou o mesmo, e isto é o mesmo

Também afinal.

Já no primeiro verso, "No acaso da rua o acaso da rapariga loira", o poeta reconhece uma coincidência, um encontro ao acaso que, desconcertantemente, revela- se como um destino adiante. Este caráter de aparente casualidade constitui um dos traços da repetição. Quem nunca se deixou tapear pela aparente casualidade de certos encontros, cujas determinações inconscientes comandam a insistência do desejo no retorno dos signos? A consciência não participa do juízo inconsciente que conspira certas razões do seu destino, que, qual automaton, move-se por si mesmo. Por isso, deste termo utilizado por Aristóteles para indicar o que se move por conta própria, Lacan se apropriou para falar da rede dos significantes, que insistiria sob o comando do desejo.

No (a)caso do poema, a rapariga loira é o signo da insistência do desejo. Todavia, o poeta flagra-se fisgado pelo engodo do acaso descomprometido, pois, depois de indicar o acaso da loira no acaso da rua, ele denuncia, no verso sete, o recordar intransigentemente, que remeteria à insistência da rede significante. Da mesma forma, a aparente liberdade do acaso, que parecia sugerir o primeiro verso, abala-se em seguida, no incisivo verso dois - "Mas não, não é aquela" -, e alcança uma constatação interrogativa radical nos versos 23-25: "Por que todas as recordações são a mesma recordação/ Tudo que foi é a mesma morte/ Ontem, hoje, quem sabe se até amanhã?".

O verso dois do poema, o "Mas não, não é aquela", abre caminho para a anunciação de algo que se repete, mas não sem alguma novidade. Trata-se de uma nova loira, mas que, em verdade, estranhamente, confunde-se com uma mesma outra, de outra rua. Isso traz à tona a nuance do novo e do mesmo na repetição. O que se repete não é reprodução, porque o objeto é sempre outro, mas isso de o objeto ser sempre outro é o que se repete na cadeia metonímica do desejo. Quer dizer, para além do retorno da rapariga loira, há a repetição do encontro faltoso.

A insistência dos signos de que Lacan nos fala é a própria insistência do desejo; a articulação temporal entre os significantes constituindo-se como presença do desejo cujo objeto absoluto falta sempre. O objeto presente, ilusão do objeto absoluto, é o que constitui o imaginário, marcado pela decepção, pela negatividade, pela castração. Entre estes dois objetos - o presente ilusório e o ausente absoluto - é que vamos situar a função do real. (GarciaRoza, 1999b, pp. 42-43)

A loira, para quem o poeta confessa escrever seus versos, é o objeto ilusório recorrente e o significante da falta. Neste sentido, com o transcorrer do poema, fica clara a confusão para se identificar a(s) rapariga(s). Alternamse os artigos e pronomes para se referir ao(s) objeto(s) rapariga(s): "a", "aquela", "a outra", "esta", "elas", "uma". Além disso, o próprio jogo com os tempos verbais denuncia a confusão de todas as loiras resultando em uma, que é 
também nenhuma. Isso se instala como impasse do verso 18: "Mas qual delas?". A resposta segue nos versos 19 a 22: "Havia uma que vi há muito tempo numa outra cidade/E houve esta que vi há muito tempo numa outra cidade". Por fim, o poeta resolve a pluralidade, a unidade e o vazio das loiras com a constatação interrogativa (ou interrogação radical constatada?) dos versos 23-25: "Por que todas as recordações são a mesma recordação/Tudo que foi é a mesma morte, /Ontem, hoje, quem sabe se até amanhã?".

Mas todas as recordações são a mesma recordação de quê? O que há de primordial em todas as recordações, nas marcas do psiquismo que se metonimiza na trama significante do desejo, é a impossibilidade da satisfação plena, mítica, que supostamente poderia ser oferecida pelo objeto perdido, das Ding, que não é propriamente perdido, pois o que o coloca nesta condição é o não surgimento do desejado, que situa o real no lugar do retorno do que escapa e não pode ser dito.

Ademais, outra coisa curiosa é o poeta enunciar, no verso 24 , na articulação de todas as recordações como uma única, a questão de tudo o que foi ser a mesma morte. Ora, a partir da assertiva de que a palavra mata a coisa, corrente na linguística e na psicanálise, pode-se dizer que o sujeito está fadado ao encontro faltoso do real nos desfiladeiros do significante. Capturado pelo simbólico, depois que a linguagem torna o organismo um corpo, e que faz do animal um ser falante, o sujeito passa a aceder à morte a partir de que, articulando uma cadeia significante, "ele sente de perto que ele pode faltar à cadeia do que ele é" (Lacan, 1997, p.354). Assim, a morte consiste num embaraço para o homem: este ser de linguagem. E o simples fato de nomear a morte, ou uma pulsão de morte, como o fez Freud, escancara de vez este embaraço.

A partir das duas últimas estrofes do poema - com a constatação de que a rapariga loira é a mesma afinal, e tudo é o mesmo afinal, inclusive o eu lírico, que não é o mesmo, é o mesmo afinal -, pode-se conjecturar que o que sempre retorna ao mesmo lugar, na condição de encontro faltoso do real, é o que termina por garantir realidade ao mundo, ou melhor, a possibilidade de tudo ser o mesmo afinal, repetindo-se e sendo diferente sempre. Por isso, Lacan recorreu a Spinoza em sua fórmula supracitada: um pensamento adequado evita sempre a mesma coisa. Evita o real na condição do impossível que sustenta a realidade.

A partir dessa concepção de sujeito da psicanálise dividido em sua condição de ser de linguagem e fadado ao encontro faltoso do real -, resta que a ética da análise, por um lado, não permanece confinada ao princípio do bom (re) encontro da felicidade no bem. Por outro lado, no que se refere ao que buscam as pessoas que chegam ao divã, não se pode também negligenciar o que elas demandam. "O que nos demandam, é preciso chamá-lo por uma palavra simples, é a felicidade. Com isso não digo nada de novo uma demanda de felicidade, de happiness, como escrevem os autores ingleses na linguagem deles" (Lacan, 1997, p. $350)$.

Ao afirmar que os analisantes demandam a felicidade, Lacan não desconsiderou que o desejo inconsciente sustenta a metonímia de qualquer demanda, nem que toda demanda é uma demanda de amor, que tem como horizonte o afastamento da castração pela miragem do próprio bem no encontro amoroso. Em análise, a demanda de felicidade se coloca, no caso a caso, sob as mais diversas condições de mal-estar e de refugo do desejo: algum embaraço sexual, uma angústia incontornável, a incapacidade de realizar um luto, uma depressão, uma anorexia etc. Assim, muito justamente, a demanda de felicidade dos analisantes resulta na vontade de ser curado, no sentido de encontrar um equilíbrio normativo consigo mesmo, reorientando-se em relação ao próprio bem.

A partir disso que se demanda ao psicanalista, podese realizar um questionamento a respeito da medida de sua ação, especialmente acerca do que ele oferta. Afinal, se existe uma ética da psicanálise é porque esta questão se coloca. De partida, o analista deve ter consciência de que não sabe, num certo limite, a medida dos efeitos da sua ação, pois, a partir da própria suposição do inconsciente, há sempre uma parte da ação que permanece velada para si mesmo. Lacan propõe, então, que, diante do que lhe resta velado em sua ação, o analista esteja advertido quanto ao seu desejo, o que não quer dizer ceder dele (Lacan, 1997, p. 350). Advertir-se quanto ao desejo resulta no cuidado do analista de evitar a miragem imaginária de uma relação dual com o analisante, com a promessa de que o sujeito possa vir a encontrar o bem que lhe falta, ou a felicidade a que aspira.

Numa perspectiva imaginária da transferência, há sempre o risco do deixar-se levar pela demanda do cliente, na crença de poder avançar incólume sobre a resistência e fundar domínio no tratamento. Em "Observações sobre o amor de transferência", Freud conta uma boa anedota, a do pastor e do corretor de seguros, para ilustrar os riscos a que está sujeito o analista que não está advertido quanto ao seu desejo e se crê senhor da situação:

O corretor de seguros, livre pensador, estava à morte e seus parentes insistiram em trazer um homem de Deus para convertê-lo antes de morrer. A entrevista durou tanto tempo que aqueles que esperavam do lado de fora começaram a ter esperanças. Por fim, a porta do quarto do doente se abriu. $\mathrm{O}$ livre pensador não havia sido convencido, mas o pastor foi embora com um seguro. (Freud, 1915/1996e, p. 183)

É preciso evitar a postura trapaceira de ser o garante 
do encontro feliz do analisante, arrastando a prática da análise para o campo do serviço dos bens. É cediço que a questão dos bens é ancestral para o homem, especialmente a do Bem Supremo. O analista sabe, contudo, que não o tem para oferecer ao seu cliente, posto que este Sumo Bem não existe. Por isso, levar uma análise adiante é deparar-se com o limite do desejo, para além do bem e do belo.

Enfim, se a análise não promete a felicidade, o bom encontro, o que ela pode oferecer de fato? No pacto da associação livre, há a franca suspensão de certas amarras da palavra, em que se dispensa a polidez, a cortesia e a coerência (Lacan, 1986, p. 202). Com o tempo, resulta deste acordo o sepultamento de certo número de falsos bens, de vaidades dos próprios dons, com a alteração de certas posições de gozo infernais, inerentes à solução de compromisso do sintoma. Aproveitando uma homofonia explorada por Lacan $^{2}$ (n.d.b), pode-se dizer que uma psicanálise converte o inconsciente saber infernal (le savoir comme enfer) encravado no sintoma, em saber-fazer (le savoir comment faire) com o sintoma, no sentido do desembaraçar-se dele através da fala. Assim, o tratamento analítico resulta no bem-dizer o sintoma, com o sujeito consumando a renuncia de certa quota de gozo autodestrutivo e conquistando "na transferência alguma outra coisa que confere sua forma a tudo o que vive - é sua própria lei, da qual o sujeito apura o escrutínio" (Lacan, 1997, p. 360).

Então, não se trata de prometer o encontro do bem. Tampouco a análise parte do princípio de que o sintoma é um mal, uma disfunção do comportamento a ser corrigida, ou um distúrbio cognitivo a ser retificado. O sintoma é a resposta que o sujeito pôde encontrar para os embaraços da sua ex-sistência. Por isso, não cabe ao analista ter pressa na extinção do sintoma, portando o furor de curar o indivíduo. Isso seria permanecer na perigosa "falcatrua benéfica do querer-o-bem-do-sujeito" (Lacan, 1997, p. 267).

Um analista precisa saber que, mesmo estando atento ao bem-estar do paciente no curso de uma análise, pautarse tão somente pelo querer-o-bem-do-sujeito é incorrer nos arriscados ideais daquele que se devota ao bem do outro. E isso é a sabotagem do sentido do sintoma para o sujeito. Neste terreno,

apenas a psicanálise reconhece esse nó de servidão

\footnotetext{
2 Na homofonia entre o savoir comme enfer (saber como inferno) e o savoir comment faire (saber como fazer, saber-fazer, knowhow), está em jogo a tese de Lacan (n.d.a) de que o equívoco homofônico veicula o mesmo saber inconsciente, apesar das divergências semânticas das expressões. O savoir comment faire é a via prática do saber como fazer, que Lacan associou ao saber inconsciente em psicanálise, pois aí reside o cerne do ethos psicanalítico acerca da ação humana. Por outro lado, em convergência com o savoir comment faire, tem-se que este saber do ethos psicanalítico é o saber no lugar da verdade subjetiva: um saber infernal (savoir comme enfer) que concerne ao desejo e queima no fogo do gozo, além do princípio do prazer.
}

imaginária que o amor sempre tem que redesfazer ou deslindar. Para tal tarefa, não há no sentimento altruísta nenhuma promessa para nós, que expomos à luz a agressividade subjacente à ação do filantropo, do idealista, do pedagogo ou do reformador. No recurso que preservamos do sujeito ao sujeito, a psicanálise pode acompanhar o paciente até o limite extático do "Tu és isto" em que se revela, para ele, a cifra do seu destino mortal, mas não está só em nosso poder de praticantes levá-lo a esse momento em que começa a verdadeira viagem. (Lacan, 1998e, p. 103)

Essa "verdadeira viagem" da análise são as voltas do analisante retramando o desejo inconsciente que move sua vida. Afinal, sustentar que a ética da psicanálise se afirma como uma ética do bem-dizer corresponde ao dizer de uma maneira mais consonante com o desejo. A livre associação evidencia que a repetição é uma operação inerente à estrutura subjetiva, na franja entre a satisfação, a fantasia e o real impossível de ser tramado num encontro pleno de felicidade com o semelhante. Wiederholen (a repetição) está próximo do sirgar do sujeito, do trem puxado por certos trilhos de onde não se consegue sair (Lacan, 1998b) - é isso que se evidencia na associação livre. Aí, como por acaso, a repetição é a celebração vaidosa do encontro falhado: o sinal mais vivo do real indomável da Coisa no estilo e no desejo de cada sujeito que aborda a realidade com seu aparelho linguageiro de gozo.

Por isso, interrogando a contingência do sintoma diante do real da pulsão que inferniza cada um no íntimo de sua ex-sistência, uma psicanálise avança com as voltas da demanda, que é sempre demanda de amor e de felicidade, até o ponto em que o sujeito se libera do sintoma de que se queixava através dos equívocos de um dizer verdadeiro, que o psicanalista recorta pacientemente com suas intervenções condutoras do tratamento. Neste sentido, as respostas do analista se garantem na ética do bem-dizer que sustenta o seu ato, cujo vetor é o que se designa por desejo do analista. E como assinala Lacan (1998d, p.260), este desejo do analista não é um desejo puro, ou seja, não está a serviço dos ideais que concernem às éticas do bem. Trata-se, por outro lado, do desejo do analista visando obter a pura diferença, a diferença absoluta que é o desejo de cada sujeito, e que se descortina no percurso da análise, com a queda dos falsos bens e dos gozos autodestrutivos inerentes à formação de compromisso do sintoma. Nestes termos, "cabe formular uma ética que integre as conquistas freudianas sobre o desejo: para colocar em seu vértice a questão do desejo do analista" (Lacan, 1998f, p. 621).

Dessa forma, pode-se constatar que a demanda do analisante e a interpretação do analista são duas distintas modalidades do dizer na cena analítica. De um lado, a 
demanda é o apelo de amor e de felicidade do analisante. Ela é o jogo das falas associativas no âmbito dos fracassos e impedimentos proclamados sob a forma de queixa, que inclui, por isso, a súplica do bem possível e necessário que a cura analítica possa vir a propiciar. Em contrapartida, $o$ ato do analista é a intervenção que ilumina a verdade inconsciente no dito do sujeito: verdade que repousa nas sombras dos ditos, nos lapsos, nas hesitações e entonações equívocas. Por isso, a diferença absoluta suportada pelo desejo do analista é o vértice de suas intervenções sobre os dizeres de uma verdade particular, que não vale para todos.

Com isso, tem-se que a ética do desejo não concorda com uma interpretação que seja teórica e explicativa, quer dizer, imperativa e com fins de convencimento. Incidindo sobre um dizer verdadeiro e particular, o ato analítico não pode ser premeditado. E não trabalhando sob o horizonte de assertivas generalizantes - como a proposição "todo homem é mortal", que nos une na morte -, o ato analítico diverge radicalmente das interpretações classificatórias e diretamente prescritivas de uma solução, como os diagnósticos psiquiátricos e os de clínica médica em geral.

Com o estabelecimento da relação de transferência, na medida em que o trabalho avança, o analista é integrado nas cadeias associativas do analisante. Somente a partir deste movimento, sua interpretação é fecunda. E mais: ao seguir com sua escuta flutuante a reverberação dos dizeres verdadeiros na demanda, o analista atua de modo tanto mais certeiro quanto mais é intempestiva sua escolha, ou seja, não calculada de antemão.

Na ética do bem-dizer, a interpretação tem valor de corte sincrônico na fala diacrônica e intencionada da demanda do analisante, que visa uma significação compartilhável. Por isso, demanda e interpretação analítica são como os dois vetores que se cruzam e se cortam em sentidos opostos, na forma elementar do grafo do desejo (Figura 1) de Lacan $(1998 \mathrm{~g})$. O corte da intervenção analítica abala a repetição de gozo e sentido fixados no sintoma. Por isso, o analista corta a fala do analisante, antecipando-lhe o ponto de basta de seu discurso, assim como valoriza os equívocos do significante, que sempre realizam e escamoteiam um dizer verdadeiro.

Contra a fixidez do pathos do sintoma, o analista segue a orientação equívoca do significante, moeda comum entre os poetas no jogo com as polifonias, a sonoridade do verbo, seus pontos de basta e significação. Neste sentido, Álvaro de Campos (Pessoa, 1998, p. 354) já versejara em seu poema "A casa branca nau preta": "É sempre melhor o impreciso que embala do que o certo que basta,/ Por que o que basta acaba onde basta, e onde acaba não basta,/ E nada que se pareça com isso devia ser o sentido da vida". De sua parte, o analista acolhe a demanda do analisante e lhe devolve a questão do seu desejo pela via dos seus equívocos significantes, produzindo ondas no sentido encravado no sintoma. Por isso, Lacan (2007, p. 35) fora taxativo na advertência de que a interpretação analítica não deve ser teórica nem sugestiva, pois dar sentido ao sintoma equivale a engrossar mais as raias da sua razão de ser.

Porque a ética do desejo se realiza como ética do bem-dizer, tendo em vista o ser falante que encarna a incontornável falta-a-ser nas voltas do circuito pulsional, a direção do tratamento é pautada pela valorização do equívoco no âmbito da materialidade significante, com fins de produzir ondas na reverberação sonora da fala do sujeito e, assim, sob o suporte da voz, abalar os alicerces significantes da formação sintomática. Ora, com Freud (1915g/1996), o impulso responsável por produzir a pressão (Drang) permanente no ser falante, no sentido da satisfação, foi denominado de pulsão. Em concordância com isso, Lacan (Lacan, 2007) postulou que a pulsão é o eco do dizer no corpo. Por isso, em análise, excluído o olhar do jogo, é a voz que se caracteriza como via da demanda através dos impulsos sonoros, mecânicos e vibrantes da fala. Assim, o objeto da pulsão invocante responde no lugar da causa real da propagação significante e de seu equívoco em análise, na qual as articulações do analisante ressoam consonantes com o que é do inconsciente (Lacan, 2007).

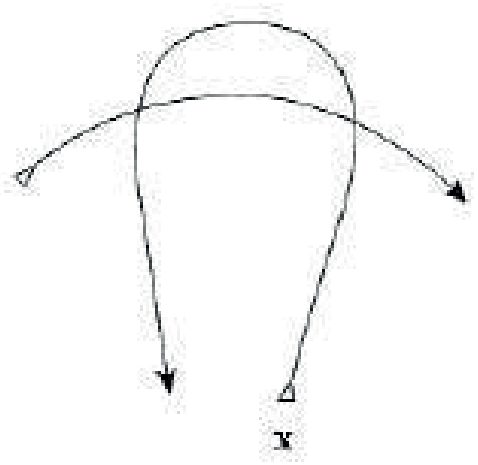

Figura 1. Grafo do desejo 
Enfim, em uma psicanálise, a demanda de felicidade do analisante é convertida em interrogação acerca do desejo do sujeito nos limites do gozo do sintoma. Isso porque a psicanálise presume um sujeito que é efeito da articulação significante, e que encarna no corpo o gozo do sintoma enquanto formação de compromisso entre instâncias tão díspares da sua ex-sistência: de um lado, o princípio do prazer, o bem, o belo e os ideais compartilhados; de outra parte, o desejo inconsciente e o gozo além do princípio do prazer. Assim, o que uma análise ambiciona é incidir no sintoma, no nível de uma intervenção significante sobre aquilo que o próprio significante fixou sob a forma de posição de gozo sintomática do ser falante. Como as naus do poema supracitado "A casa branca nau preta" (Pessoa, 1998, p. 354), as análises seguem a rota e o ritmo particular dos sujeitos desejantes. "E a rota que devem seguir estava escrita nos ritmos,/ Os ritmos perdidos das canções mortas dos marinheiros de sonho...".

\section{Referências}

Arendt, H. (2002). Entre o passado e o futuro. São Paulo: Perspectiva.

Aristóteles (1979). Ética a nicômaco. (Coleção Os Pensadores). São Paulo: Abril Cultural.

Aristóteles (2002). Ética eudemia. Madrid: Alianza Editorial S.A.

Benjamin, W. (1996). Obras escolhidas I - Magia e técnica, arte e politica/ ensaios sobre literatura e história da cultura. ( $7^{\mathrm{a}}$ ed.). São Paulo: Brasiliense.

Foucault, M. (1984). História da sexualidade 2: O uso dos prazeres. Rio de Janeiro: Edições Graal.

Freud, S. (1980). A negativa. In J. Strachey (Ed.), Edição Standard Brasileira das Obras Psicológicas Completas de Sigmund Freud (Vol. 19). (Originalmente publicado em 1925)

Freud, S. (1996a). Projeto para uma psicologia científica In J. Strachey (Ed.), Edição Standard Brasileira das Obras Psicológicas Completas de Sigmund Freud (Vol. 1, pp. 333-454). Rio de Janeiro: Imago. (Originalmente publicado em 1895)

Freud, S. (1996b). A Interpretação dos sonhos. In J. Strachey (Ed.), Edição Standard Brasileira das Obras Psicológicas Completas de Sigmund Freud (Vol. 4 e 5). Rio de Janeiro: Imago. (Originalmente publicado em 1900)

Freud, S. (1996c). Além do princípio do prazer. In J. Strachey (Ed.), Edição Standard Brasileira das Obras
Psicológicas Completas de Sigmund Freud (Vol. 18, pp. 11-75). Rio de Janeiro: Imago. (Originalmente publicado em 1920)

Freud, S. (1996d). Sobre o narcisismo: uma introdução. In J. Strachey (Ed.), Edição Standard Brasileira das Obras Psicológicas Completas de Sigmund Freud (Vol. 14, pp. 75-108). Rio de Janeiro: Imago. (Originalmente publicado em 1914)

Freud, S. (1996e). Observações sobre o amor transferencial (Novas recomendações sobre a técnica da psicanálise III). In J. Strachey (Ed.), Edição Standard Brasileira das Obras Psicológicas Completas de Sigmund Freud (Vol. 12, pp. 173-190). Rio de Janeiro: Imago. (Originalmente publicado em 1915)

Freud, S. (1996f). O inconsciente. In J. Strachey (Ed.), Edição Standard Brasileira das Obras Psicológicas Completas de Sigmund Freud (Vol. 14, pp. 163-222). Rio de Janeiro: Imago. (Originalmente publicado em 1915)

Freud, S. (1996g). Os instintos e suas vicissitudes. In J. Strachey (Ed.), Edição Standard Brasileira das Obras Psicológicas Completas de Sigmund Freud (Vol. 14, pp. 115-144). Rio de Janeiro: Imago. (Originalmente publicado em 1915)

Freud, S. (1997). O Mal-estar na civilização. In J. Strachey (Ed.), Edição Standard Brasileira das Obras Psicológicas Completas de Sigmund Freud (Vol. 21). Rio de Janeiro: Imago. (Originalmente publicado em 1930)

Garcia-Roza, L. A. (1999a). Introdução à metapsicologia freudiana: Artigos de metapsicologia, 1914-1917. (3a ed., Vol. 3). Rio de Janeiro: Jorge Zahar Ed.

Garcia-Roza, L. A (1999b). Acaso e repetição em psicanálise: Uma introdução à teoria das pulsões. Rio de Janeiro: Jorge Zahar Ed.

Heidegger, M. (1991). Carta sobre o humanismo. São Paulo: Editora Moraes.

Jadin, J.-M., \& Ritter, M. (2009). La jouissance au fil de l'enseignement de Lacan. Toulouse: Éditons Érès.

Julien, P. (1996). O Estranho gozo do próximo. Rio de Janeiro: Jorge Zahar Ed.

Kant, I. (1959). Crítica da razão prática. São Paulo: Ed. Edigraf.

Lacan, J. (1976). Conférences et entretiens dans des universités nord-américaines (1975). In J. Lacan, Scilicet 6/7. Paris: Éditions du Seuil. 
Lacan, J. (1985). O Seminário, livro 20: Mais ainda (197273). Rio de Janeiro: Jorge Zahar Ed.

Lacan, J. (1986). O Seminário, livro 1: Os escritos técnicos de Freud (1953-54). Rio de Janeiro: Jorge Zahar Ed.

Lacan, J. (1988). Conferencia en Ginebra sobre el sintoma (1975). In J. Lacan, Intervenciones y textos 2 (pp. 115144). Buenos Aires: Editiones Manantial.

Lacan, J. (1992). O Seminário, livro17: O avesso da psicanálise (1969-70). Rio de Janeiro: Jorge Zahar Ed.

Lacan, J. (1997). O Seminário, livro 7: A ética da psicanálise (1959-60). Rio de Janeiro: Jorge Zahar Ed.

Lacan, J. (1998a). A instância da letra no inconsciente ou a razão desde Freud. In J. Lacan, Escritos (pp. 496-533). Rio de Janeiro: Jorge Zahar Ed.

Lacan, J. (1998b). A significação do falo. In J. Lacan, Escritos (pp. 692-703). Rio de Janeiro: Jorge Zahar Ed.

Lacan, J. (1998c). Função e campo da fala e da linguagem. In J. Lacan, Escritos (pp. 238-324). Rio de Janeiro: Jorge Zahar Ed.

Lacan, J. (1998d). O Seminário, livro 11: Os quatro conceitos fundamentais da psicanálise (1964). Rio de Janeiro: Jorge Zahar Ed.

Lacan, J. (1998e). O estádio do espelho como formação da função do eu tal como nos é revelada na experiência analítica. In J. Lacan, Escritos (pp. 96-103). Rio de Janeiro: Jorge Zahar Ed.

Lacan, J. (1998f). A direção do tratamento e os princípios de seu poder. In J. Lacan, Escritos (pp. 591-652). Rio de Janeiro: Jorge Zahar Ed.

Lacan, J. (1998g). Subversão do sujeito e dialética do desejo no inconsciente freudiano. In J. Lacan, Escritos (pp. 807-842). Rio de Janeiro: Jorge Zahar Ed.

Lacan, J. (2003). Radiofonia. In J. Lacan, Outros Escritos (pp. 403-447). Rio de Janeiro: Jorge Zahar Ed.

Lacan, J. (2007). O Seminário, livro 23: O sinthoma (197576). Rio de Janeiro: Jorge Zahar Ed.

Lacan, J. (n.d.a). O Seminário, livro 21: Les non-dupes errent (1973-74). Paris: Éditions de l'Association Freudienne Internationale: Publication hors commerce. (Originalmente registrado em 1973-74)

Lacan, J. (n.d.b). O Seminário, livro 25: Le moment de conclure (1977-78). Paris: Éditions de l'Association Freudienne Internationale: Publication hors commerce. (Originalmente registrado em 1977-78)

Mora, J. F. (2001). Dicionário de filosofia (Tomos I a IV).
São Paulo: Edições Loyola.

Pessoa, F. (1998). Obra poética. Rio de Janeiro: Editora Nova Aguilar S.A.

Sófocles (2001). A trilogia tebana ( $9^{\mathrm{a}}$ ed.). Rio de Janeiro: Jorge Zahar Ed.

\section{Endereço para correspondência:}

Caio de Mattos Filho

Endereço: Rua Professor Sabino Silva, 356/901, Jardim Apipema, Salvador/BA. CEP: 40155- 250. Tel: (71) 32354534. E-mail: caiomfilho@yahoo.com.br

\section{Endereço para correspondência:}

Maria Angélia Teixeira

Endereço: Avenida Anita Garibaldi, 1133, Centro OdontoMédico Itamaraty, s.803, Ondina, Salvador/BA. CEP: 40.170-130. Tel: (71) 3235-4245.

E-mail: angelia@campopsicanalitico.com.br 